\title{
THE EVOLUTION OF ECONOMIC RELATIONS BETWEEN ROMANIA AND THE SUB-SAHARAN STATES BEFORE DECEMBER 1989 AND IN THE FIRST TWO DECADES OF TRANSITION
}

Alba-Iulia Catrinel POPESCU, PhD*

The decolonization of sub-Saharan Africa was an opportunity intelligently speculated by the communist regime in Bucharest. Unlike the other communist states, regimented to the ideological current imposed by Moscow, Romania promoted an independent foreign policy and sought to establish economic relations with all developing states, regardless of their political orientation. But the events of December 1989 radically changed Romania's policy towards sub-Saharan states. This article proposes an analysis of the way in which the economic relations between Romania and the sub-Saharan states evolved before the events of December 1989 and in the first two decades of the transition to a market economy.

Keywords: Sub-Saharan Africa; G 77; EU-Africa Strategic Partnership; December 1989; Department for Middle East and Africa.

For 21 years, between 1968 and 1989, Romania was one of the main economic partners of the sub-Saharan states. Sensing the opportunity offered by decolonization, the communist regime in Bucharest became the most vocal

\footnotetext{
* Alba-Iulia Catrinel POPESCU, PhD. is an Associate Professor at the National Defence College, within the "Carol I" National Defence University, Bucharest, Romania. E-mail: albapopescu1@gmail.com
} 
and visible partner of the new post-colonial states, regardless of their political orientation. However, Romania's economic relations with the sub-Saharan space were radically influenced by the political, geopolitical, social and ideological changes subsequent to the events of December 1989.

In the following pages we will review the main areas of economic cooperation between Romania and its sub-Saharan partners and how these economic relations evolved before and after the events of December 1989, in the first two decades of the transition to a market economy.

\section{The Cold War Period}

Sub-Saharan African states have faced major structural economic imbalances since independence, translated by the dualism generated by the coexistence of archaic barter economic practices with modern ones, as well as the fracture of the economic system due to minimal or absent correlations between sectors of national economies. These imbalances, associated with the underdevelopment following the years of colonialism, the inexperience of leaders and the stakes of geostrategic players active on the African continent have fully contributed to the current failure of African states' industrialization and, in some cases, even state bankruptcy.

Becoming a market for consumer goods and exporting raw materials, African countries have experienced trade deficits, which have deepened over time. To this state of affairs, the following have contributed:

- the economic imbalance generated by Western direct investments, which mainly targeted public services and the extractive sector;

- full repatriation of profits by investors;

- the unfavorable credit system granted by international financial institutions to African states, given the risk factors associated with these young democracies;

- the economic crises of the late 1970s and early 1980s, which reduced the interest of potential Western investors in African economies.

Although the Western credit system of the 1970s, somehow more flexible in terms of creditworthiness criteria, allowed the financing of development projects in the sub-Saharan states, in the 1980s, when the due date came, the beneficiaries of the loans were unable to pay and went into recession.

In this economic context, the "third world" states laid the foundations of the Group of 77 (G77), Romania being the only state in the Warsaw Pact ${ }^{1}$

${ }^{1}$ N.A.: The Treaty of Friendship, Cooperation and Mutual Assistance, founded on May 14, 1955
in the Polish capital, was a military alliance of the countries of the Soviet Union (USSR) and the
Eastern Bloc, directed against the Western Bloc led by the United States of America (US). It officially 
that became a member of this forum (acquiring observer status in the NonAlignment Movement), as a result of the political-diplomatic support granted, in the international institutions, to the national liberation movements and, later, to the developing states. As in the case of political-diplomatic relations, the period after 1968 can be considered the period of opening and flourishing of our country's economic relations with African states.

In this sense, since 1968, between Romania and the sub-Saharan states, economic and technical-scientific cooperation agreements, bilateral trade and payment agreements, protocols and economic cooperation contracts were signed, the development of which was analyzed annually, during the intergovernmental mixed commission meetings ${ }^{2}$.

In 1973, the first visits took place at the highest level, of a Romanian government delegation in Senegal and Morocco $^{3}$ and, after 1974, the trade relations with the African states acquired a special weight. Romania's economic presence in the sub-Saharan states has strengthened political and diplomatic relations and vice versa, being a relationship of mutual empowerment between the two categories of exchanges and bilateral relations. The motivation of our country's orientation towards the sales markets of the "third world" states was an extremely pragmatic and realistic one: these markets, which represented over three quarters of the world's population, although extremely sensitive in terms of sales costs, were less sensitive to quality and innovation, being able to offer cheap raw materials in return.

Romania has obtained advantageous ocean fishing licenses in the territorial waters of Mauritania and Namibia on the basis of which the fishing fleet and the related canning and fishery products industry have developed ${ }^{4}$. Romania has also received from sub-Saharan partners the right to exploit energy and mineral deposits, in exchange for investments in transport infrastructure, arms exports ${ }^{5}$

ceased to exist on July 1, 1991, in Prague. See: Petre Opriş, România în Organizaţia Tratatului de la Varşovia (1955-1991), Militară Publishing, Bucharest, 2008.

${ }^{2}$ Gheorghe Zaman, George Georgescu, A retrospective study on Romania's external trade in the past 100 year, Munich Personal RePEc Archive, October 2018, p. 22, URL: https://mpra.ub.unimuenchen.de/89707/1/MPRA_paper_89707.pdf, accessed on 10.07.2021.

$3 * * *$, Politica externă - repere cronologice III (1971 - 1980), Comunismul în România, 11 March 2015, URL: https://www.comunismulinromania.ro/index.php/politica-externa-repere-cronologiceiii-1971-1980/, accessed on 10.07.2021.

${ }^{4}$ Nicolae Zărnescu, “Întreprinderea de Pescuit Oceanic - unicat al industriei alimentare din economia socialistă”, Linia Întâi, 23.10.2013, URL: http://linia1.ro/intreprinderea-de-pescuit-oceanic-unicatal-industriei-alimentare-din-economia-socialista/, accessed on 11.07.2021.

5 ***, "Peştii, armele şi spionii. Ce legătură este între flota românească de pescuit, războaiele din Africa şi căderea lui Ceauşescu", ProTV, 28.09.2014, URL: http://stirileprotv.ro/emisiuni/2014/ sezonul-2/pestii-armele-si-spionii-ce-legatura-este-intre-flota-romaneasca-de-pescuit-razboaieledin-africa-si-caderea-lui-ceausescu.html, accessed on 23.06.2021. 
and cooperation in the field of education ${ }^{6}$. In order to maintain its presence on sub-Saharan markets and to exploit the mineral and energy resources offered by African partners, Romania has set up joint companies, such as Carombois and Lorombois in the Central African Republic, Nirowi in Nigeria, Socaton SAPM (Romagrimex) in the Republic of Congo, ZAIROM in Zaire, Besaminco in Tanzania ${ }^{7}$ and Simar, created in partnership with economic agents in Mauritania ${ }^{8}$.

Enterprises such as Tractorul Braşov, Semănătoarea Bucureşti, Progresul Brăila, ARO Câmpulung, Dacia Piteşti, Romcim, Rompetrol, Arcom, Geomin, Uzinexportimport, Oltchim Râmnicu Vâlcea, Azomureş have become well known in the African space, Romanian products being appreciated by the beneficiaries so far. According to a study by Ambassador Marcel Dinu ${ }^{9}$, in Burundi, a Romanian geologist discovered one of the most important nickel deposits in the world, in Nigeria, Romanian specialists provided technical assistance to the Nigerian National Petroleum Corporation (NNPC) and in Angola, in 1985, Romanian specialists built oil depots in the city of Huambo, worth about 10 million US dollars ${ }^{10}$. To these were added other large-scale projects, completed by Romanian companies, such as:

- the Sudanese Parliament building in Khartoum ${ }^{11}$ and other civil constructions in Nigeria, Ghana, Cameroon, etc.;

- oil and mining operations in Nigeria, Zambia, Kenya, Burundi, Senegal, Guinea;

- construction of road transport infrastructure in Nigeria, Ghana;

\footnotetext{
${ }^{6}$ Ilarion Ţiu, "Republica Africa Centrală, la picioarele lui Ceauşescu", Historia, URL: https://www. historia.ro/sectiune/general/articol/republica-africa-centrala-la-picioarele-lui-ceausescu, accessed on 23.06.2021.

7 ***, Raport privind creanțele României la 31 iunie 2005, provenite din activitatea de export, cooperarea economică internațională si alte acțiuni externe, derulate inainte de 31 decembrie 1989 , Ministry of Public Finance, 28.06.2006, URL: http://www.cdep.ro/bperm/2006/F26954-creante.pdf, accessed 23.06.2021.

8 ***, ACORD din 24 septembrie 1987 intre Guvernul Republicii Socialiste România şi Guvernul Republicii Islamice Mauritania privind cooperarea în domeniul pescuitului maritim şi activitătile conexe, URL: http://legislatie.just.ro/Public/DetaliiDocumentAfis/22686?fbclid=IwAR2Hm6CD17 AWVyBf3i3cQUgmp8WEWI7MNi9GXzcmUt8KRT08r_mJEpWz7QU, accessed on 10.07.2021.

${ }^{9}$ Marcel Dinu, "Unele considerente referitoare la extinderea relaţiilor României cu statele din Africa, Asia, America Latină şi Orientul Mijlociu în a doua jumătate a secolului XX", URL: http://www. irsea.ro/Rela--355-ii-externe-secolul-XX/, accessed on 23.11.2014.

10 ***, Relaţii bilaterale Republica Angola, Direcţia Orientul Mijlociu şi Africa din Ministerul Afacerilor Externe, URL: http://www.mae.ro/bilateral-relations/1809\#699, accessed on 23.11.2014. 11 ***, "Pe urma miliardelor pierdute ale României socialiste, investite în afară", Romania Military, 26.04.2012, URL: http://www.rumaniamilitary.ro/pe-urma-miliardelor-pierdute-ale-romanieisocialiste-investite-in-afara, accessed on 23.04.2017.
} 
- construction of airport transport infrastructure in Mozambique, Senegal;

- development of agricultural crops in Mozambique, Central African Republic, Congo and Zaire - R.D. Congo;

- drinking water drilling in Zambia ${ }^{12}$.

The memorialist of the first Romanian Pan-African expedition, the biologist Nicolae Coman, said that during the trip behind the wheel of the ARO SUV, manufactured in Câmpulung Muscel, the members of the expedition were surprised by Romania's notoriety in the states they traveled and by the impressive number of Africans who had developed either economic or educational ties with our country. Among the many surprising meetings with Romanians settled in Africa or with Africans educated in Romania, Coman recalled the meeting with the representatives of the Sudan-Romania Friendship Association, which had 10,000 members, or the meetings with locals in Burundi, graduates of the faculties of medicine, geology and construction in Romania, which at that time held governmental leadership positions ${ }^{13}$.

In the $1980 \mathrm{~s}$, in the context of the international isolation to which the communist regime in Bucharest was subjected, both by Westerners and by the "fraternal states" of the Soviet bloc, the African market became one of the favorite targets of Romanian foreign trade enterprises. Even if there were numerous damaging contracts, signed exclusively for ideological reasons, to help "fraternal countries", or for reasons related to the cult of personality of President Nicolae Ceaușescu (1918-1989), who wanted to demonstrate his status as a world political leader, on the whole, the trade balance was in favor of our country and the bilateral relations served the economic and political interests of Romania.

The main products imported by Romania from sub-Saharan African states were non-food raw materials (crude oil, bauxite and other non-ferrous ores, cotton, etc.), and the main Romanian products exported to sub-Saharan Africa were food, chemicals, plants, machinery, construction materials and so on ${ }^{14}$.

12 ***, Traditiia relaţiilor româno-africane, Direcţia Orientul Mijlociu şi Africa din cadrul Ministerului Afacerilor Externe, Bucharest, 2009, p. 2.

${ }^{13}$ Nicolae Coman, De la Atlantic la Oceanul Indian. Insemnările unui biolog din prima expediţie românească trans-africană (1970-1971), Dacia Publishing, Cluj Napoca, 1975, pp. 10-30.

${ }^{14}$ Gheorghe Zaman, George Georgescu, op.cit., p. 29. 


\section{MILITARY HISTORY}

Table no. 1: The volume of Romania's commercial transactions with African states (millions of lei in foreign currency, during that year) ${ }^{15}$

\begin{tabular}{|c|c|c|c|c|c|}
\hline \multirow{3}{*}{ Angola } & Year & 1980 & 1985 & 1987 & 1989 \\
\hline & Export & 82.7 & 117.6 & 27.5 & 64.7 \\
\hline & Import & 203.7 & 1.8 & - & - \\
\hline \multirow{3}{*}{ Ivory Coast } & Year & 1970 & 1980 & 1985 & 1987 \\
\hline & Export & 0.9 & 23.8 & 7.2 & 68.7 \\
\hline & Import & - & 46.2 & 83.9 & 2.9 \\
\hline \multirow{3}{*}{ Ethiopia } & Year & 1970 & 1980 & 1987 & 1989 \\
\hline & Export & 0.7 & 19.4 & 97.6 & 24.6 \\
\hline & Import & - & 23.2 & 36.4 & 48.8 \\
\hline \multirow{3}{*}{ Ghana } & Year & 1970 & 1980 & 1985 & 1989 \\
\hline & Export & 3.1 & 2.4 & 84.7 & 29.5 \\
\hline & Import & 3.7 & 31.2 & 151.6 & 26.0 \\
\hline \multirow{3}{*}{ Guinea } & Year & 1970 & 1980 & 1985 & 1989 \\
\hline & Export & 2.0 & 0 & 43.5 & 2.8 \\
\hline & Import & 3.0 & - & 112.6 & 7.5 \\
\hline \multirow{3}{*}{ Nigeria } & Year & 1970 & 1980 & 1985 & 1989 \\
\hline & Export & 16.3 & $1,399.5$ & $1,384.5$ & 729.6 \\
\hline & Import & - & 160,9 & - & 1.2 \\
\hline \multirow{3}{*}{ Sudan } & Year & 1960 & 1970 & 1985 & 1989 \\
\hline & Export & 9.5 & 24.7 & $1,028.6$ & 107.6 \\
\hline & Import & 4.81 & 13.6 & 391.1 & 9.6 \\
\hline \multirow{3}{*}{ Tanzania } & Year & 1970 & 1985 & 1987 & 1989 \\
\hline & Export & 0.5 & 17.2 & 219.4 & 157.2 \\
\hline & Import & - & 1.0 & 157.8 & 62.8 \\
\hline \multirow{3}{*}{$\begin{array}{c}\text { Zaire } \\
\text { (current } \\
\text { R.D.Congo) }\end{array}$} & Year & 1980 & 1985 & 1987 & 1989 \\
\hline & Export & 3.0 & 21.2 & 61.6 & 22.0 \\
\hline & Import & 147.3 & - & 26.2 & 2.6 \\
\hline
\end{tabular}

According to the data provided by the Statistical Yearbook of Romania ${ }^{16}$ (see Table no. 1), in 1985 the maximum level of commercial transactions between Romania and a series of sub-Saharan states was reached, very tender in terms of resources and size of the market, such as: Angola, Ghana, Guinea, Nigeria, Sudan, Tanzania, Zaire (now DR Congo). In the case of Ethiopia and the Ivory Coast, the maximum volume of bilateral trade transactions was reached in 1987.

Analyzing the dynamics of trade transactions with Nigeria and Sudan, we find that in 1980, Romania imported a volume of goods worth 1,399.5 million lei foreign currency from Nigeria, and in 1985, it imported a volume of goods worth 1,028.6 million lei currency from Sudan. In the 1970s and 1985s, the volume 15 ***, Anuarul Statistic al României 1980-1989, apud. Nicolae Melinescu, Uriaşul care se trezeşte, CA Publishing, Bucharest, Cluj Napoca, 2009, vol. 2, pp. 91-92.

${ }^{16}$ Ibidem. 
of Romanian imports from Nigeria was zero. The explanation for this massive increase in Romanian imports from the two African states is related to the Islamic Revolution in Iran, from 1979, which determined the reorientation of the regime from Bucharest to other sources of crude oil. In 1985, a putsch took place in Nigeria, overthrowing General Muhammadu Buhari and replacing General Ibrahim Babangida. The instability generated by the Nigerian political crisis was reflected in the volume of trade transactions.

Corroborating the dynamics of the diplomatic activity of the Bucharest regime in the mentioned space with the data illustrated in the table in Figure no. 1, the close link between the political and economic factor in the bilateral relations between Romania and the sub-Saharan states, the ascending route during the 1970s and the first half since the 1980s, as well as the orientation of the Romanian state towards those attractive African economies in terms of energy and mineral raw materials.

\section{The Period Preceding Romania's Accession to the EU}

The economic restructuring of Romania in the 1990s, through deindustrialization and the change of foreign policy priorities, put in the background the economic relations with the African states, all the more so as they, in their turn, went through intense periods of internal transformations, on the background of changing local geostrategic players. As a result, since 2014, only seven of the 28 Romanian embassies opened before 1989, to which the South African embassy was opened, opened on November 21, 1991, have been operating in the sub-Saharan area. The activity of these Romanian embassies in Nigeria, South Africa, Angola, Sudan, Senegal, Kenya, Ethiopia, Zimbabwe is completed on the consular line of 16 honorary consulates, open in states where there are Romanian citizens: Nigeria (4 consulates), Benin, Guinea, Guinea Bissau, Mali, Mauritania, Mozambique, Niger, Senegal, South Africa, Central African Republic, Ivory Coast, Republic of the Congo. However, the closure of 20 embassies affected both the Romanian capital of influence in the sub-Saharan space, and the economic and military relations ${ }^{17}$ developed with the sub-Saharan states. Due to diplomatic disengagement, important licenses were lost, such as ocean fishing or exploitation of energy and mineral deposits, Romanian products gradually disappeared from the sub-Saharan market occupied by former competitors in eastern or western space, and Romania's claims in sub-Saharan Africa, worth billions of dollars (US) and convertible rubles, were either taken for granted by various companies, some with contact addresses via

\footnotetext{
${ }^{17}$ A.N.: Information about the subject can be found in: Alba Iulia Catrinel Popescu, "Aspecte cu privire la evoluţia relaţiilor militare dintre România şi statele subsahariene înainte şi după evenimentele din decembrie 1989”, Buletinul Universităţii Naţionale de Apărare „,Carol I”, vol. 4, nr. 2/2017, Universitatea Naţională de Apărare „Carol I” Publishing House, pp. 17 - 26.
} 
offshores ${ }^{18}$, or were deleted by government decisions.

According to a report issued by the Ministry of Public Finance, on June 30, 2005 , the total volume of Romania's receivables, resulting from export activity and other external actions carried out before December 31, 1989, was $\$ 2.2114$ billion on the convertible currency ratio and 1050.8 million rubles transferable. Of these amounts, Sudan owed \$ 169.85 million and 881825 pounds, Mozambique $\$ 165.3$ million, Nigeria $\$ 12.58$ million $^{19}$.

In 2007, the total volume of Romania's receivables had decreased by 1.427 billion dollars and 1.099 billion transferable rubles.

With a generosity worthy of the great world economies, the governments that ruled Romania in the first decade of the third millennium erased or diminished these debts through international treaties and agreements such as the Paris $\mathrm{Club}^{20}$. For example, Mozambique, a country rich in strategic minerals, which owed Romania 135 million dollars and whose government was willing to pay through mining properties, did not cede any property to the Romanian state, and also remained with a diminished debt of only $\$ 12.4$ million $^{21}$. Guinea, the sub-Saharan state that owns more than 33 percent of the world's bauxite reserves, ${ }^{22}$ owed $\$ 20.67$ million. By a government decision, the same authorities in Bucharest gave up over $90 \%$ of the debt, reducing it to two million dollars. And, in the case of the debt of 10.6 million dollars of the Central African Republic, a country rich in non-ferrous ores, they took the decision to remove it, by law, from the off-balance sheet records of public accounting. Five debtor countries - Sudan, the Republic of Congo, Nigeria, Somalia, Tanzania - accumulated debts of more than $\$ 190$ million, of which about $\$ 170$ million was the debt of Sudan alone, state rich in hydrocarbons and nonferrous ores. At that time, the Romanian authorities had not started any negotiations for the recovery of these claims ${ }^{23}$. Only R.D. Congo (Zaire), whose undersoil is rich

18 ***, "Pe urma miliardelor pierdute ale României socialiste, investite în afară", Romania Military, op. cit.

19 ***, Raport privind creanţele României la 31 iunie 2005, provenite din activitatea de export, cooperarea economică internațională şi alte acțiuni externe, derulate înainte de 31 decembrie 1989, op.cit.

${ }^{20}$ A.N.: The Paris Club is an informal group of official creditors whose role is to find coordinated and lasting solutions to the payment difficulties faced by debtor countries. See URL: https://clubdeparis. org/, accessed on 23.08.2021.

${ }^{21}$ Daniel Ionaşcu, "Aici sunt banii dumneavoastră. Miliarde de dolari, risipite de România prin investiții în alte țări”, Libertatea, 01.07.2018, URL: https://www.libertatea.ro/stiri/aici-sunt-baniidumneavoastra-miliarde-de-dolari-risipite-de-romania-prin-investitii-alte-tari-2312134, accessed on 23.08.2021.

${ }^{22}$ Alba Iulia Catrinel Popescu, Jucătorul din umbră, Militară Publishing, Bucharest, 2016, p. 60.

$23 * * *$, "Romania are de recuperat creanțe de 1.472 mld. dolari, din 15 state", Wall Street, 12.03.2007, URL: https://www.wall-street.ro/articol/Economie/26511/Romania-are-de-recuperat-creante-de-1472-mld-dolari-din-15-state.html, accessed on 23.08.2021. 
in diamonds, cobalt, tantalum and other strategic and gold ores ${ }^{24}$, had a regulated debt of $\$ 595$ million.

Even later, the amounts recognized by the debtor states were not fully recovered by the Romanian state. In 2019, the total volume of bad debts was $\$$ 716 million and 1.5 billion transferable rubles, of which $\$ 241.3$ million $(33.70 \%)$ were outstanding debts to Sudan, Nigeria, the Central African Republic, Somalia, Tanzania and Libya ${ }^{25}$.

The causes of the non-recovery of these debts by the Romanian state, as it results from the above mentioned report are "the major economic, financial and foreign exchange difficulties faced by some African countries, whose debts to Romania amount to 376.4 million US dollars (17\% of total claims), qualified to receive assistance under the HIPC (high indebtedness poor countries, the poorest in the world): Sudan, Guinea, Central African Republic, Republic of the Congo, DR Congo, Mozambique, Somalia, Tanzania and "membership of debtor countries, already part of the HIPC program", in the categories of "conflict-affected countries" and "post-conflict countries" to receive additional financial support from international bodies : R. Central African Republic, R. Congo, RD Congo, Somalia, Sudan $^{26}$.

\section{The Period of the First Decade since Romania's Accession to the EU}

Romania's accession to the European Union on January 1, 2007 and the adjustment of Romanian policies to the community ones, including the EU-Africa Strategic Partnership ${ }^{27}$, marked an economic recovery of the Romanian state in the African space, even if much lower compared to the 1970s-1980.

Until the date of Romania's accession to the EU, the legal framework of the Romanian-African trade was ensured by the treaties, agreements, protocols and agreements signed by the Romanian state, before 1989, with the African states. After our country became a member of the European Community, these documents have become obsolete, thus the process of updating them is currently underway.

\footnotetext{
${ }^{24}$ Alba Iulia Catrinel Popescu, op.cit., pp. 90-107.

25 ***, "Document: România are de încasat creanţe de 716 milioane dolari şi 1,5 miliarde ruble transferabile", Mediafax, 29.07.2019, URL: https:/www.mediafax.ro/economic/document-romaniaare-de-incasat-creante-de-716-milioane-de-dolari-si-1-5-miliarde-de-ruble-transferabile-18252848, accessed on 23.08.2021.

26 ***, Raport privind creanțele României la 31 iunie 2005, provenite din activitatea de export, cooperarea economică internațională şi alte acțiuni externe, derulate înainte de 31 decembrie 1989, op.cit.

27 ***, The Africa-EU Partnership, URL: http://www.africa-eu-partnership.org/en/about-us/whatpartnership, accessed on 29.10.2015.
} 
According to the data provided by the Ministry of Foreign Affairs (MFA) ${ }^{28}$, during the analyzed period, Romania exported to the sub-Saharan states chemical fertilizers, plastics, kerosene, Dacia Logan/Duster cars, tractors and spare parts, bearings, electrical and household appliances, car tires, articles of paper, cardboard, wood, glass, faience, fabrics and knitwear, construction materials (iron, steel, cast iron), wire, grain, table wine.

During the same period, Romanian imports from African countries focused mainly on raw materials: oil (Sudan), tropical wood, cocoa, precious stones, rubber, cotton, tea, coffee, fish and shellfish, spices, fruits, raw hides and skins of sheep, cattle, goats, manganese ore, bauxite (Guinea, Sierra Leone), iron (Republic of South Africa-RAS), coal (RAS).

\subsection{Trade between Romania and Angola}

Currently, the Romanian-Angolan economic relationship is regulated by the Protocol of cooperation between the Romanian and Angolan foreign ministries, signed in $2008^{29}$.

According to the data provided by the Department for Middle East and Africa within the MFA, the Romanian exports to Angola were mainly made up of chemical fertilizers, electrical appliances, Dacia-Logan cars.

The graph in Figure no. 1 shows the oscillating evolution of trade between Romania and Angola, with a revival of exports during 2012 and 2013 and a significant decrease in 2015. It is interesting to note that Romanian imports from this African state are virtually equal to zero, given that Angola is one of the most bidding states in terms of production of hydrocarbons, precious metals, diamonds, rare metals, uranium, etc.

Unfortunately, after 2015 there are no official public reports of the Romanian Embassy in Angola on the dynamics of trade between the two states.

${ }^{28}$ N.A.: According to the MFA, in the case of the Republic of South Africa (R.S.A.) "Romania's accession to the E.U. led to the renegotiation of the existing Trade, Development and Cooperation Agreement (T.D.C.A.) between the E.U. and R.S.A., by introducing Romania and Bulgaria as countries that will benefit from tariff facilities, etc. offered by this legal framework. Based on the Aquis Communitaire process, trade and economic cooperation agreements were repealed by mutual agreement, being replaced by the existing Trade Development and Cooperation Agreement between the E.U. and R.S.A. (Trade Development Cooperation Agreement-T.D.C.A.)", in ***, Relaţii bilaterale Republica Africa de Sud, Direcţia Orientul Mijlociu şi Africa, Ministry of Foreign Affairs, URL: http://www.mae.ro/bilateral-relations/1772\#746, accessed on 23.11.2014 and in ***, Relații bilaterale, Ambasada României în Republica Africa de Sud, URL: https://pretoria.mae.ro/node/170, accessed on 12.09.2021.

29 ***, "Republica Angola", URL: https://www.mae.ro/bilateral-relations/1809, accessed on 23.07.2021. 


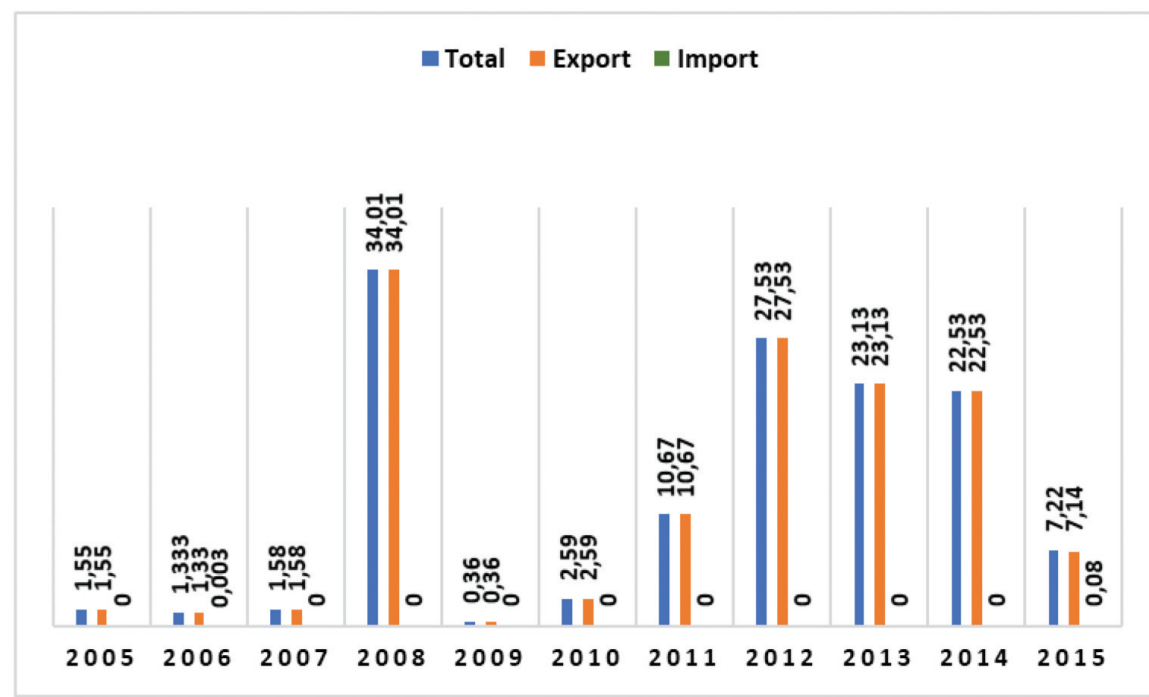

Figure no. 1: The dynamics of Romania - Angola trade in 2005-2015 (millions of dollars) ${ }^{30}$

\subsection{Trade between Romania and the Republic of South Africa}

According to the M.F.A., until 1990, Romania did not maintain direct trade relations with South Africa, the trade transactions taking place through intermediaries from third countries.

In the early 1990s, a series of legal documents were concluded between the two states, such as: Trade Agreement (1990); Economic Cooperation Agreement (1993); Agreement on the avoidance of double taxation (1993); Agreement on the abolition of visas for diplomatic and service passports (1995); Cooperation agreement between the Chamber of Commerce and Industry of Romania and the Federation of Chambers of Commerce of the Republic of South Africa (1991); Memorandum on the Statute of the Joint Intergovernmental Commission for Economic and Technical Cooperation $(1994)^{31}$

The graph in Figure no. 2 presents the dynamics of trade between Romania and South Africa in the period 2006-2013. A first observation is related to the growing trade surplus on the Romanian side, the last four years of the reporting period registering a significant increase in exports. Another observation refers to the acceleration of Romanian exports starting with 2008, after Romania's accession to the EU and the adjustment of the Romanian foreign policy in accordance with the European one (the EU-Sub-Saharan Africa strategic partnership being a European political imperative).

30 ***, Relaţii economice, Ambasada României în Republica Angola, URL: https://luanda.mae.ro/ node/168, accessed on 23.07.2021.

31 ***, Republica AFRICA de SUD, Ministerul Afacerilor Externe, URL: https://www.mae.ro/ bilateral-relations/1772, accessed on 23.07.2021. 


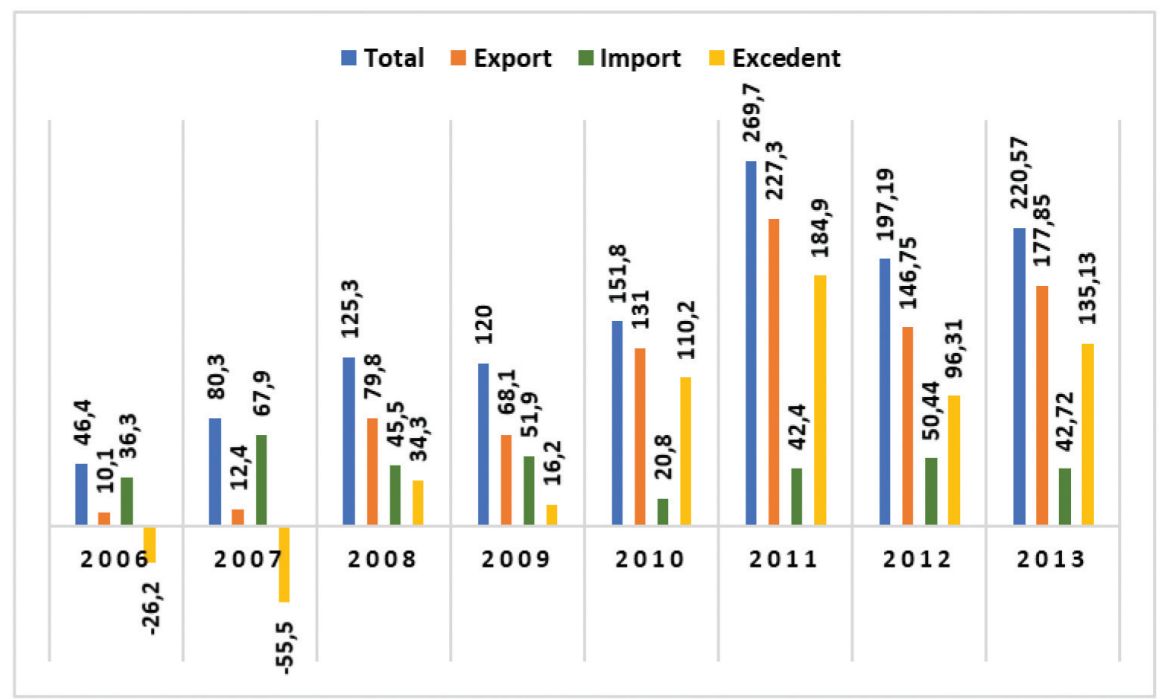

Figure no. 2: The dynamics of Romania - South Africa trade in 2006-2013 (millions of dollars) ${ }^{32}$

According to M.F.A., Romanian exports to R.S.A. consisted of: "ships, cement, polyester fibers, chemicals and petrochemicals, plastics, glass products, gas tanks, transmission equipment, ceramics, metallurgy, urea, furniture, rubber, etc.' and, imports from R.S.A. targeted "iron, coal, wine, alcoholic beverages, textiles, industrial machinery, semi-finished gold products, wool, meat and fish, protein substances, pumps, paper, tobacco, asbestos, hides, chemicals, fruit juices, etc."33.

In February 1996, the South African company South African Breweries (S.A.B.) took over the majority stake of \$ 18 million from the S.C. Vulturul Buzău S.A., being the first major capital investment in a sub-Saharan country in Romania. Subsequently, South African shareholders invested another \$ 100 million by taking over the Ursus brewery in Cluj and Pitesti. At the level of 2013, the South African investments in our country exceeded the value of 500 million euros, in fields such as telecommunications $(N A S P E R S)$, real estate $(N E P L)$, car subassemblies $(M E T A I R)$. Bilateral economic exchanges are stimulated by the annual visits of Romanian economic missions, as well as by the participation of economic agents from both states in the annual international fairs organized in Romania, such as the Bucharest International Fair (T.I.B.) and the International Consumer Goods Fair (T.I.B.C.O.), in South Africa, The Southern African International Trade Exhibition for Retail Products (S.A.I.T.E.X.) - The South African International Exhibition of Retail Goods and Africa Aerospace \& Defense, where the Romanian participation

32 ***, Relaţii bilaterale Republica Africa de Sud, Direcţia Orientul Mijlociu şi Africa, Ministerul Afacerilor Externe, URL: http://www.mae.ro/bilateral-relations/1772\#746, accessed on 23.11.2014. 33 ***, Relaţii bilaterale Republica Africa de Sud, op.cit. 
takes place at the national flag level. Unfortunately, after 2013 there are no official public reports of the Romanian Embassy in South Africa on the dynamics of trade between the two states ${ }^{34}$.

\subsection{Trade between Romania and Ethiopia}

According to the M.F.A., bilateral trade between Romania and the Democratic Federal Republic of Ethiopia is governed by cooperation agreements, such as:

- Convention between Romania and R.F.D. Ethiopia for the avoidance of double taxation and the prevention of tax evasion with respect to taxes on income and on capital, which entered into force on 9 May 2009;

- The Cooperation Protocol between the Chamber of Commerce and Industry of Romania and the Chamber of Commerce and Sectoral Associations of Ethiopia (E.C.C.S.A.), which entered into force on April 25, 1995.

Romania's exports to Ethiopia were represented by "cereals, chemicals, plastics, wood, paper and cardboard, ceramics, glass and glassware, construction materials (cast iron, iron and steel), DACIA cars, products of aeronautical industry and the import industry consists of coffee, tea, spices, raw hides and skins of cattle, sheep and goats".

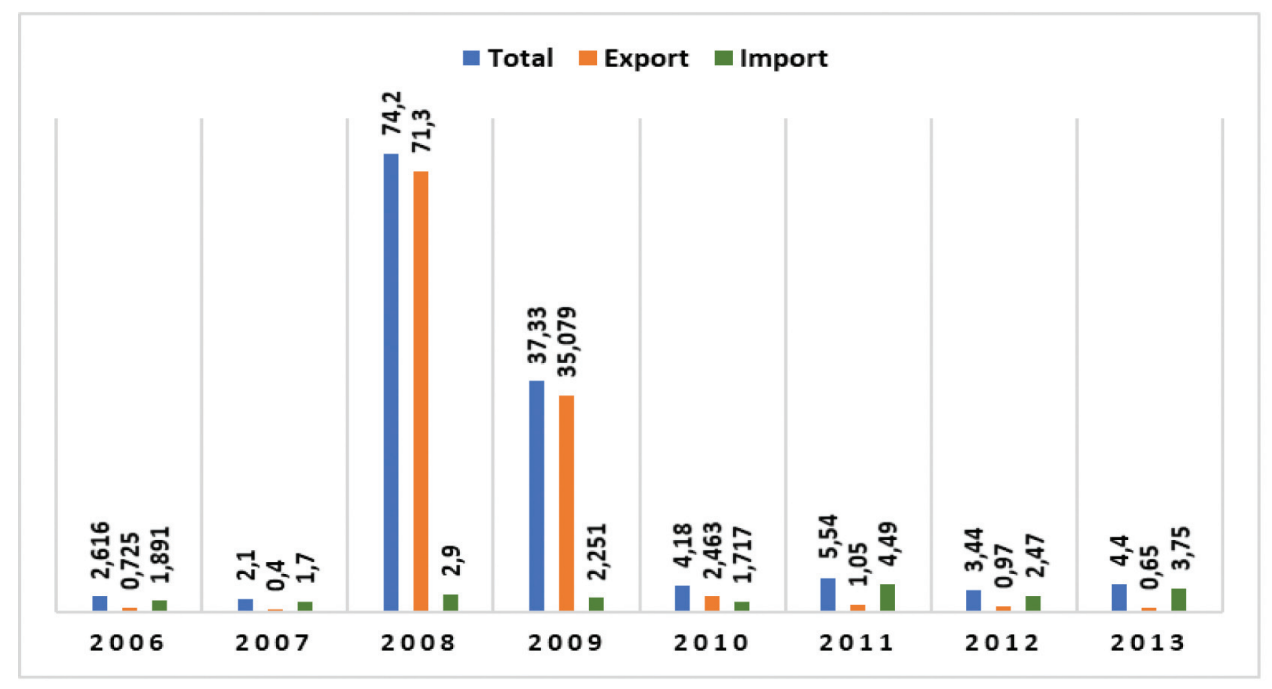

Figure no. 3: The dynamics of Romania - Ethiopia trade in 2006-2013 (millions of dollars) ${ }^{35}$

\footnotetext{
${ }^{34}$ Ibidem.

35 ***, Relaţii bilaterale Republica Federală Democratică a Etiopiei, Direcţia Orientul Mijlociu şi Africa din Ministerul Afacerilor Externe, URL: http://www.mae.ro/bilateral-relations/1854\#719, accessed on 23.11.2014.
} 
The increased values of Romanian exports during the years 2008 - 2009 in the chart in Figure no. 3 are largely related to the situation of Ethiopian agricultural production, affected by the prolonged drought and the depletion of national grain reserves. The food supply situation in Ethiopia has been exacerbated by the massive immigration from Somalia of the conflict- and drought-stricken population.

\subsection{Trade between Romania and Sudan}

According to the MFA, on May 31, 2007, the Convention for the avoidance of double taxation between Romania and Sudan was signed in Bucharest, and got in force in November 2009. In July 2008, in order to respond to European legislation, it was agreed that three important documents in the economic field should cease to be valid: the Economic and Technical Cooperation Agreement, the Trade Agreement and the Program Agreement for the Long-Term Development of Economic and Technical Cooperation and Trade" ${ }^{36}$. However, there are other normative acts in the economic field signed before 1989, which are still in force, such as: The Sanitary-Veterinary Convention between the Government of S.R. Romania and the Government of R.D. Sudan (signed in Khartoum on 28.08.1974) and the Agreement between the Government of S.R. Romania and the Government of R.D. Sudan on air services between and beyond their own territories (signed in Bucharest on 13.05.1978 ${ }^{37}$ ).

Romania exported to Sudan "food products, chemicals, pharmaceuticals and perfumery, plastic and rubber products, mineral oils, metallurgical products, cast iron products (oil drilling pipe), railway equipment, spare parts for internal combustion engines, wood and wood products, paper, cement, textiles" ${ }^{\prime 38}$. The same source states that "the Republic of Sudan offers business opportunities mainly in the fields: oil, car construction, agriculture, light industry, electricity" and that, "negotiations are underway to conclude important contracts in the field of oil and to build a cement factories in Sudan" 39 .

Between February 21-23, 2012, in Khartoum, the works of the Romania - Sudan Economic Forum took place, organized by the Sudanese Ministry of Petroleum, in coordination with the Romanian Embassy, attended by "representatives of 27 Romanian companies in the oil fields, electricity and construction, as well as Sudanese officials and businessmen." ${ }^{\prime 40}$ If we refer to the data included in the graph

36 ***, Cadru juridic bilateral, Ambasada României în Republica Sudan, URL: https://khartoum. mae.ro/node/170, accessed on 23.07.2021.

${ }^{37}$ Ibidem.

38 ***, Relaţii bilaterale Republica Sudan, Direcţia Orientul Mijlociu şi Africa din Ministerul Afacerilor Externe, URL: http://www.mae.ro/bilateral-relations/1767\#747, accessed on 23.11.2014. ${ }^{39}$ Ibidem.

$40 * * *$, Relaţii bilaterale - Scurt istoric, Ambasada României în Republica Sudan, URL: https:// khartoum.mae.ro/node/221, accessed on 12.09.2021. 
in Figure no. 5, the Forum did not end in special results, in 2013 the economic relations suffered a contraction due to the imports from Sudan, although, in terms of Romanian exports on the Sudanese market, there was an increase of about 3 million dollars.

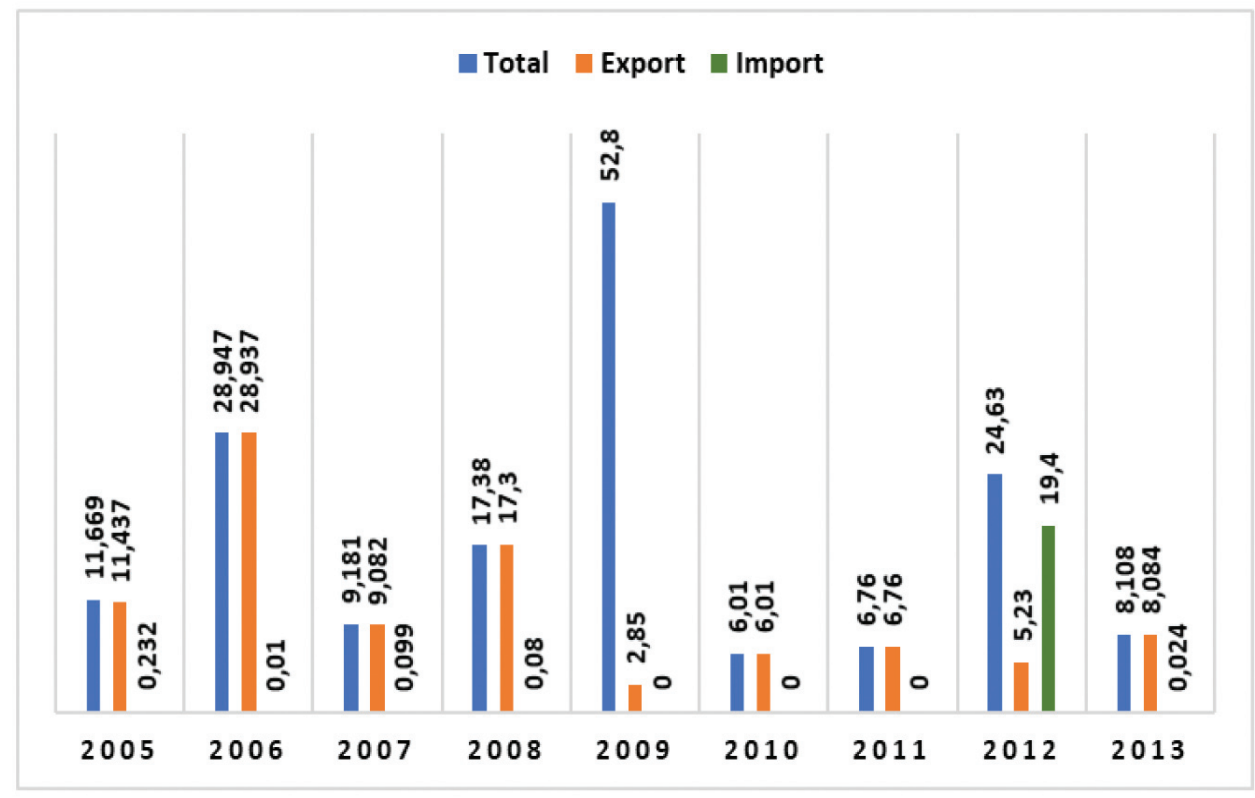

Figure no. 4: The dynamics of Romania - Sudan trade in 2005-2013 (millions of dollars) (1 $^{4}$

The graph in Figure no. 4 illustrates the dynamics of trade between Romania and Sudan in the period 2005-2013, where there is a significant increase in the volume of Romanian imports in 2012, most likely secondary to the diplomatic efforts mentioned above. Although Sudan is extremely tender in terms of energy and mineral resources, political instability and the international diplomatic isolation of the Khartoum regime are reflected in the low volume of economic exchanges that Romania has developed since 1989 with this African state. Unfortunately, after 2013 there are no official public reports of the Romanian Embassy in Sudan on the dynamics of trade between the two states.

\subsection{Trade between Romania and other sub-Saharan states}

Table no. 2 illustrates the volume of bilateral trade transactions between Romania and 17 sub-Saharan African states, at the level of 2013.

41 ***, Relaţii bilaterale Republica Sudan, Direcţia Orientul Mijlociu şi Africa din Ministerul Afacerilor Externe, URL: http://www.mae.ro/bilateral-relations/1767\#747, accessed on 23.11.2014. 
Table no. 2: The volume of bilateral trade transactions between Romania and sub-Saharan African states in 2013 (millions of dollars) ${ }^{42}$

\begin{tabular}{|c|c|c|c|}
\hline State & Total Volume & Export & Import \\
\hline Burkina Faso & 7.10 & - & - \\
\hline Cameroon & 6.426 & 5.686 & 0.74 \\
\hline Ivory Coast & 10.216 & 9.019 & 0.197 \\
\hline Gabon & 10.44 & 10.42 & 0.02 \\
\hline Ghana & 6.715 & - & - \\
\hline Guinea & 26.13 & 1.11 & 25.02 \\
\hline Kenya & 25.38 & - & - \\
\hline Madagascar & 2.677 & 2.40 & 0.277 \\
\hline Mali & 2.60 & 2.60 & - \\
\hline Mauritania & 30.00 & 28.5 & 2.50 \\
\hline Mauritius & 2.623 & 0.283 & 2.34 \\
\hline Mozambique & 7.43 & 5.23 & - \\
\hline Nigeria & 35.323 & - & 0,007 \\
\hline Senegal & 12.869 & 12.862 & 24.977 \\
\hline Sierra Leone & 25.809 & 0.932 & - \\
\hline Togo & 166.943 & 166.943 & 6.20 \\
\hline Zambia & 7.55 & 1.35 & \\
\hline
\end{tabular}

A first observation is related to the increased volume of these trade with West African states, compared to the states in other sub-Saharan development regions. The volume of Romanian exports to Togo is remarkable, a state with just over 7.5 million inhabitants ${ }^{43}$, while the volume of only $\$ 35.32$ million of economic exchanges with Nigeria is insignificant, compared to the market of over 177 million of inhabitants and to the extremely bidding potential of the Nigerian economy. With the exception of countries such as Guinea, Kenya, Mauritania and Sierra Leone, where bilateral trade exceeds $\$ 20$ million, in other cases the volume of trade transactions is insignificant.

If we analyze the level of Romanian imports and corroborate these data with the nature of the main raw materials offered by the partner states, we can deduce the level and structure of the current industrial branches of the Romanian national economy. For example, the only more significant import activities were carried out in Guinea and Sierra Leone, countries rich in bauxite, a raw material used in the aluminum industry, still functional in our country. Otherwise, states bidding for copper, cobalt, zinc and iron ores, such as Zambia, or holders of important deposits of hydrocarbons, uranium, strategic ores, such as Nigeria, Mozambique,

${ }^{42}$ A.N: Data presented on the Internet by M.F.A., Department for Middle East and Africa.

43 ***, "TOGO", CIA World Factbook, URL: https://www.cia.gov/library/publications/the-worldfactbook/geos/to.html, accessed on 29.10.2015. 
Madagascar, Gabon are almost non-existent on the map of Romanian imports of materials, as a sign that domestic industries which may have been interested in such products no longer exist or are sourced from other sources. It should be mentioned that Romania's current economic relations with former trading partners such as Botswana, Burundi, Republic of Cape Verde, Central African Republic, Chad, Djibouti, R.D. Congo, Congo, Guinea Bissau, Equatorial Guinea, Seychelles, Somalia are also insignificant, some of these African states being, today, crushed by civil conflicts (Somalia, R.D. Congo, Burundi, Central African Republic).

\section{Conclusions}

The apogee of Romania's relations with the sub-Saharan states was reached during the 1980s, amid multiple bilateral political and economic partnerships, as well as the isolation of the Bucharest regime from both the Western bloc states and the communist bloc states. Under these conditions, the sub-Saharan states, like other poor states in Asia and Latin America, became the main economic partners of the communist Romania. Bilateral relations are not always economically advantageous for the Romanian state, given that, in some cases, they were deeply ideological and that they also served propaganda needs. However, during the mentioned period, Romania benefited from multiple economic advantages from the "third world" states-category that also includes the sub-Saharan states - expressed by low purchase prices of raw materials, advantageous licenses for exploitation of mineral deposits and energy or fishery resources.

At the end of the 1980s, Romania had accumulated debts of billions of dollars, which were largely lost in the years before our country's accession to the European Union. The loss of these claims was the result of a series of disastrous political decisions, which led to regional diplomatic disengagement and the cancellation of much of the debt accumulated by sub-Saharan states, although some of these debts could be recovered through concession and exploitation rights of some ore deposits or oil fields, or their repayment could be postponed until a later date when the debtor state could pay the debts.

In the same years preceding the accession of our country to the community structures, on the principle that "Romanian industry is a pile of scrap metal", there was deindustrialization and radical change of Romania's economic profile, from an industrializing country to a country for supplying services and raw materials and a market for imported products. Under these conditions, in the absence of the need for cheap African raw materials, Romania's economic and political-diplomatic presence in the sub-Saharan area diminished to extinction in many of the states once financed and politically supported in Bucharest. This political decision taken by the governments that led Romania in the analyzed period to the loss of markets, then of 
receivables, of regional influence, of access to strategic ores and hydrocarbons and, finally, of the state power.

Romania's accession to the EU and the EU-Africa Strategic Partnership marked a return to the diplomatic presence and Romanian products on the subSaharan markets, but much below the level reached during the communist regime, when Romania held, for the first time in its history, the status of active geostrategic player in a space outside its own borders, in this case in sub-Saharan Africa.

It should be recalled that the current sub-Saharan market, which is growing in population and economy, is extremely attractive to industrial powers such as China, India, France, the Russian Federation, Australia, the USA, Israel or Japan, which have developed multi-level partnerships with sub-Saharan states, taking over both the directions of action used by the Romanian policy in the region, in the period preceding the events of 1989, as well as the markets owned by the Romanian companies. Economic attractiveness generated by the competition for the control of strategic ore sources, raw materials of current and future industrial revolutions, but also by a series of particularities of these markets, less sensitive to quality criteria, but very sensitive to price criteria, criteria to which China and India qualify without problems. Criteria that Romania would have qualified if, instead of destroying much of its industrial heritage, it chose to refurbish at least part of it.

Unfortunately, the diplomatic disengagement, the changing profile of the national economy, the global economic challenges following the medical crisis generated by the SARS-CoV-2 virus, as well as the instability in certain regions of the subcontinent, continue to maintain a low level of Romanian products in sub-Saharan markets. Situation unlikely to change in the near or medium future and which will lead to the total loss of influence gained with huge financial effort during the communist period, with the biological disappearance of generations of African intellectuals educated in Romanian schools and universities before December 31, 1989.

\section{BIBLIOGRAPHY:}

1. ***, "Pe urma miliardelor pierdute ale României socialiste, investite în afară", România Military, 26.04.2012, URL: http://www.rumaniamilitary.ro/peurma-miliardelor-pierdute-ale-romaniei-socialiste-investite-în-afara

2. ***, "Peştii, armele şi spionii. Ce legătură este între flota românească de pescuit, războaiele din Africa şi căderea lui Ceauşescu", ProTV, 28.09.2014, URL: http://stirileprotv.ro/emisiuni/2014/sezonul-2/pestii-armele-şi-spionii-ce-legaturaeste-între-flota-romaneasca-de-pescuit-razboaiele-din-africa-şi-caderea-luiceauşescu.html

3. ***, "Republica AFRICA de SUD”, Direcţia Orientul Mijlociu şi Africa din Ministerul Afacerilor Externe, URL: http://www.mae.ro/bilateral- 
relations/1772\#746

4. ***, "România are de recuperat creante de 1.472 mld. dolari, din 15 state", Wall Street, 12.03.2007, URL: https://www.wall-street.ro/articol/Economie/26511/ Romania-are-de-recuperat-creante-de-1-472-mld-dolari-din-15-state.html

5. ***, "TOGO", CIA - The World Factbook, URL: https://www.cia.gov/ library/publications/the-world-factbook/geos/to.html

6. ***, Raport privind creanţele României la 31 iunie 2005, provenite din activitatea de export, cooperarea economica internationala si alte actiuni externe, derulate inainte de 31 decembrie 1989, Ministerul Finantelor Publice, 28.06.2006, URL: http://www.cdep.ro/bperm/2006/F26954-creante.pdf

7. ***, Relaţii bilaterale Republica Africa de Sud, Direcţia Orientul Mijlociu şi Africa din Ministerul Afacerilor Externe, URL: http://www.mae.ro/bilateralrelations/1772\#746

8. ***, Relaţii bilaterale Republica Angola, Direcţia Orientul Mijlociu şi Africa, Ministerul Afacerilor Externe, URL: http://www.mae.ro/bilateralrelations/1809\#699

9. ***, Relaţii bilaterale Republica Federală Democratică a Etiopiei, Direcţia Orientul Mijlociu şi Africa, Ministerul Afacerilor Externe, URL: http://www.mae. ro/bilateral-relations/1854\#719

10. ***, Relaţii bilaterale Republică Sudan, Direcţia Orientul Mijlociu şi Africa, Ministerul Afacerilor Externe, URL: http://www.mae.ro/bilateralrelations $/ 1767 \# 747$

11. ***, The Africa-EU Partnership, URL: http://www.africa-eu-partnership. org/en/about-us/what-partnership

12. ***, Tradiţia relaţiilor româno-africane, Direcţia Orientul Mijlociu şi Africa, Ministerul Afacerilor Externe, Bucureşti, 2009.

13. COMAN, N., De la Atlantic la Oceanul Indian. Insemnările unui biolog din prima expediţie românească trans-africană (1970-1971), Editura Dacia, Cluj Napoca, 1975.

14. DINU, M., "Unele considerente referitoare la extinderea relațiilor României cu statele din Africa, Asia, America Latină şi Orientul Mijlociu în a doua jumătate a secolului XX”, URL: http://www.irsea.ro/Rela--355-ii-externe-secolul-XX/

15. IONAŞCU, D., "Aici sunt banii dumneavoastră. Miliarde de dolari, risipite de România prin investiții în alte țări”, Libertatea, 01.07.2018, URL: https://www. libertatea.ro/stiri/aici-sunt-banii-dumneavoastra-miliarde-de-dolari-risipite-deromania-prin-investitii-alte-tari-2312134

16. MELINESCU, N., Uriaşul care se trezeşte, Volumul 2, CA Publishing, Bucharest, 2009.

17. POPESCU, A.I.C., Jucătorul din umbră, Militară Publishing House, Bucharest, 2016. 
18. ȚIU, I., "Republica Africa Centrală, la picioarele lui Ceauşescu", Historia, URL : https://www.historia.ro/secţiune/general/articol/republica-africa-centrală-lapicioarele-lui-ceauşescu

19. ZĂRNESCU, N., "Întreprinderea de Pescuit Oceanic - unicat al industriei alimentare din economia socialistă", Linia Întâi, 23.10.2013, URL: http://inia1.ro/ intreprinderea-de-pescuit-oceanic-unicat-al-industriei-alimentare-din-economiasocialista/ 